\title{
CONSIDERATIONS ON CONSUMER PERCEIVED RISK
}

\author{
Laura Cătălina Țimiraş \\ "Vasile Alecsandri” University of Bacau \\ timiras.laura@ub.ro
}

\begin{abstract}
In this article we identified a number of factors influencing the consumers' perceived risk. In the first part we conducted a review of the main issues that define the perceived risk by the consumer at the time of purchase, some of the lines of action of the organizations to diminish this risk perception and a number of influencing factors presented in the literature, with significant impact on the intensity with which risk is perceived by consumers. The second part of the article is based on the statistical information regarding e-commerce market, market in which the perceived risk plays an important role in the purchasing decision. Thus, based on available official statistics provided by Eurostat we have revealed the existence of certain links between electronic commerce and orientation towards risk and income levels, age and consumer educational level. The review is not intended to be exhaustive, the study taking into consideration only those links that can be identified from using official statistical data.
\end{abstract}

\section{Keywords}

perceived risk; factors influencing perceived risk; online market

\section{JEL Classification}

M31

\section{Introduction to the consumers perceived risk}

In the process of purchasing consumer perceives a risk, which can be defined as (Ashley, 1995) „... that level of risk a consumer believes exists regarding the purchase of a specific product from a specific retailer, whether or not that belief is factually correct”. The author identifies six categories of perceived risk, as follows:

- $\quad$ Functional - refers to extent to which the product raise up to expectations;

- Physical - refers to the extent to which the product may bring personal injury;

- $\quad$ Social - refers to peer opinion on purchased product;

- Psychological - refers to the extent that the purchase is the right thing;

- Financial - refers to the affordability of purchase in terms of price;

- $\quad$ Time - refers to the time and effort required by the purchase.

The extent to which these risks are perceived varies from one consumer to another, from one product to another and even from one purchase to another for the same consumer or product, depending on the context of acquisition. There are therefore a number of factors acting on the intensity with which the risk is perceived by consumers, some of the influences being generally valid for most consumers and for most purchased products.

The perceived risk is directly dependent on the degree of novelty of a product. This is maximum for products that are new and decreases for products for which there is an prior experience. Regarding the raised issue, it is estimated that only a small part of the brand new products succeed beyond the launch phase, the associated risk factor representing brakes in purchasing decision. Also, in the case of new products is well known that the diffusion rate is relatively slow, risk of first procurement being 
undertaken initially by a small number of customers (innovators). On the other hand, expenditures associated with R\&D of new products are huge, so that the companies introducing new products on the market must have the resources to not be affected financially until the diffusion of new products grows. Under the these circumstances, it is obvious that the risk that consumers perceive in relation to new products bring organizations facing a difficult decision, ie either make the decision to launch new products (which may or may not pass the start-up phase and, also involve significant expenditure) or decide to become imitators of existing products launched by competitors (in which case the associated expenditures are lower) and perceived risk by consumers is diminished. However, such a decision may be influenced by the organization's reputation in the market, the perceived risk associated with a new product launched by a prestigious company being much lower than that associated with a similar product in terms of the degree of novelty, but released by little-known organization.

The financial risk associated with entry into new markets is significant for many producers, context in which firms use established brands to enter new markets, extending the line (using a known brand for placing a product in the same class of products) or using extension of brand (using a known brand for placing a product in a different class of goods) (Aaker and Keller, 1990). This decision is based on the fact that consumers perceive notorious brands as less risky, fact that increases the chances for first-time purchases (in Srivastava \& Sharma, 2011 taken by: Baker et al., 1986; de Chernatony, 2001; Dowling \& Staelin, 1994; de Ruyter and Wetzels, 2000), so that one of the tools at the disposal of organizations to reduce the perceived risk by the consumer is the brand.

It is known that the level of trust between brand, and more brand loyalty, and perceived risk associated with the purchase of a product exists a reverse link. The more the brand enjoy greater trust/loyalty, the less is the perceived risk by the consumer. In fact, the intensity of risk aversion varies from one consumer to another, consumers who show a high level of risk aversion being those who tend to be more loyal (Matzler, Grabner-Kräuter \& Bidmon, 2008).

Organizations efforts to obtain consumer loyalty to the brand is focused on positioning strategies that are designed to educate consumers about the cause for which their products are the best choice compared to competing products, the development of successful positioning strategies having a real effect in reducing the risk for purchases that have both low and high levels of involvement (Tian-Que, 2011).

Beyond the indisputable role of implementing successful positioning strategies in reducing the perceived risk by consumers and obtaining consumer loyalty, organizations, as owners of premium brands, are significantly affected by the counterfeiting. Firms offering counterfeit goods illegally use the notoriety of a certain brand, benefiting from its value. This illegal practice extended worldwide in all market sectors, generating real damage to brand image, leading to falling consumer confidence and thus increasing consumers' perceived risk in relation to the subject of counterfeits brands. In 2000, international trade with counterfeit goods was estimated at $\$ 100$ billion and had between three and six percent of trade in goods (Delener, 2000).

Another element that generates differences on consumers' perceived risk is the value of the product to be purchased. From this point of view there are products that involve a high degree of perceived risk (expensive products, long-use products etc.) and products which do not involves a high degree of risk (consumer goods, involving a reduced effort in acquisition, etc.).

Finally, two products launched by organizations from different countries will enjoy a different associated perceived risk depending on the consumer experience in relation 
to the products originally from the respective countries. This difference is generated precisely by what the literature calls "country of origin effect," defined as "the extent to which the place of manufacture influences product evaluations" (Gurhan-Canlia \& Maheswaran, 2000).

Country of origin refers to the place where the product was manufactured or assembled as identified by the "made in" or "Manufactured in". The effect of country of origin and brand awareness can generate a synergistic effect on consumer perception. The well-known brands were born in countries rated favorably by consumers at least in terms of covered product category, their very existence contributing to favorable or unfavorable perceptions about the country of origin. In this case, brand image and country of origin effect will contribute together to reduce the risk perceived by the consumer.

If the producing country does not enjoy positive acclaim, country of origin effect can affect both strong and weak brands. Thus, research has shown that where a product was manufactured in a country unfavorably evaluated, even when it is sold under well-known brand, the latter effect may not be able to destroy entirely the country of origin effect (Chu Chang, Chen \& Wang 2010). On the other hand, in the context of the increasing number of multinational companies and therefore the manufacture of products / components in a number of countries, the assessment of the effect of country of origin becomes difficult. Thus, consumers can identify certain notorious brands with the country of origin of the company, even if those products have been processed in other countries (Shirin \& Kambiz Heidarzadeh, 2011), which, in terms of perceived risk will be an advantage.

\section{Influencing factors on perceived risk by consumers in the online market in Europe}

Online shopping, as is well known, is associated with a high level of perceived risk. This is why further on, based on the official Eurostat statistics, we sought to identify a number of factors influencing the use of electronic commerce and thus the perceived risk as restrictive factor in buying in this king of market.

In EU countries in 2013, 47\% of the total population and $61 \%$ of Internet users have made online purchases. The differences are still great from country to country. Thus, in Romania, in 2013, only 8\% of the population has made online purchases, while in the UK and Denmark percentage was $77 \%$ (Table 1). It is obvious that the standard of living of the population influence the access to the Internet and thus manifesting as buyers in the market of electronic commerce. This is why it is relevant the comparison between countries in terms of percentage of those who have made online purchases in total Internet users. Thus, given this indicator, we found major differences between countries, online purchases being mainly specific to countries with a standard of living above average, while the last position in this regard (percentage of people who purchases online in total people who have used the Internet) lies Romania and Bulgaria. 
Table 1. Proportion of people who made online purchases in the total population and in the total number of persons who used the Internet, and GDP per capita (data for the year 2013)

\begin{tabular}{|c|c|c|c|}
\hline Country & $\begin{array}{l}\% \text { in total } \\
\text { population }\end{array}$ & $\begin{array}{c}\text { \% in total } \\
\text { individuals who } \\
\text { used Internet } \\
\text { within the last year }\end{array}$ & $\begin{array}{c}\text { GDP / } \\
\text { inhabitant }\end{array}$ \\
\hline European Union (28 countries) & 47 & 61 & 25700 \\
\hline Belgium & 48 & 57 & 34500 \\
\hline Bulgaria & 12 & 22 & 5500 \\
\hline Czech Republic & 36 & 48 & 14200 \\
\hline Denmark & 77 & 81 & 44400 \\
\hline Germany & 69 & 80 & 33300 \\
\hline Estonia & 23 & 28 & 13900 \\
\hline Ireland & 46 & 57 & 35600 \\
\hline Greece & 25 & 40 & $17400^{*}$ \\
\hline Spain & 32 & 43 & 22300 \\
\hline France & 59 & 70 & 31300 \\
\hline Croatia & 26 & 39 & 10100 \\
\hline Italy & 20 & 32 & 25600 \\
\hline Cyprus & 25 & 37 & 19000 \\
\hline Latvia & 32 & 42 & 11600 \\
\hline Lithuania & 26 & 37 & 11700 \\
\hline Luxembourg & 70 & 74 & 83400 \\
\hline Hungary & 28 & 38 & 9900 \\
\hline Malta & 46 & 65 & 17200 \\
\hline Netherlands & 69 & 73 & 35900 \\
\hline Austria & 54 & 66 & 37000 \\
\hline Poland & 32 & 49 & 10100 \\
\hline Portugal & 25 & 38 & 15800 \\
\hline Romania & 8 & 15 & 7100 \\
\hline Slovenia & 36 & 49 & 17100 \\
\hline Slovakia & 44 & 55 & 13300 \\
\hline Finland & 65 & 71 & 35600 \\
\hline Sweden & 73 & 76 & 43800 \\
\hline United Kingdom & 77 & 85 & 29600 \\
\hline
\end{tabular}

It is evident, therefore, that a potential factor braking online purchases is the purchasing power of the population, those with a high standard of living assuming greater risk in online purchases. Of course, the large share of those who buy on the Internet in the richer countries of Europe is justified by custom developed for such purchases, usually formed also in the context of a high standard of living.

Analyzing the relationship between the percentage of those who used the Internet and have made online purchases and GDP / capita in the 28 EU countries, we can confirm the idea that there is some link between the living and the habit of making purchases on the Internet. Thus, as shown in figure 1, about $50 \%$ of the variation in the percentage of those who used the Internet and have made online purchases is explained by the variation in GDP / capita (Figure 1). 


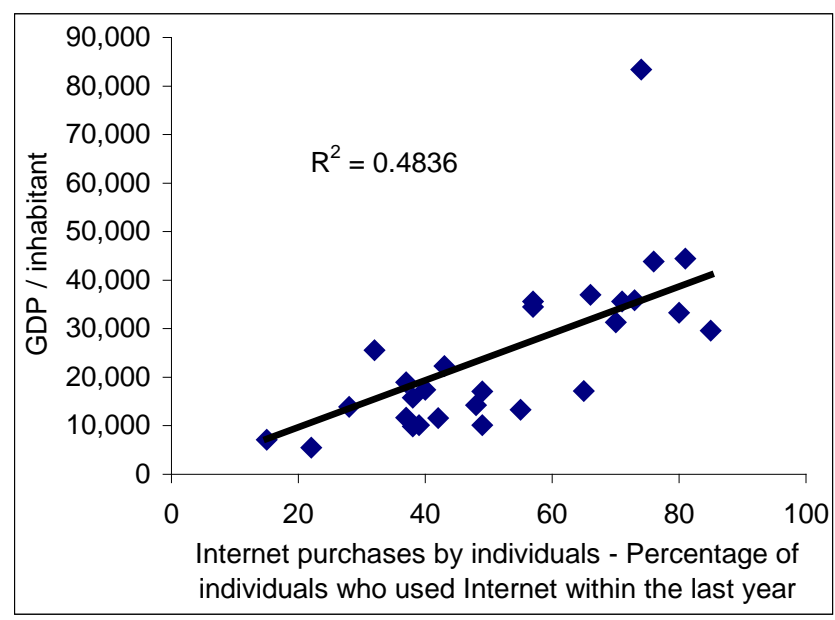

Figure 1. The relationship between the percentage of those who used the Internet and have made online purchases and standard of living (expressed as GDP / capita) in the $28 \mathrm{EU}$ countries (data for the year 2013)

* for Greece, not having data for GDP / capita in 2013, was considered the indicator of 2012

Source: Processing by Eurostat, 2014

The relationship between income and inclination to electronic commerce is perhaps the most obvious when making a comparative analysis, at state level, of the share of population who made online purchases in the total population that used the Internet for the category of people by income levels (Table 2). Thus it appears that (except for a few isolated cases) in all EU countries revenue growth was accompanied by a greater inclination to buy on the Internet (those on the first groups by income levels have made purchases on the Internet in a lesser extent, compared to those enrolled in higher income groups), confirming the idea that implicitly higher revenues generates greater openness to risk taking.

Table 2 Proportion of people who made purchases online in total population who used the Internet per category by revenues (data for the year 2013)

\begin{tabular}{|l|c|c|c|c|}
\hline Country & $\begin{array}{c}\text { Individual living } \\
\text { in a household } \\
\text { with income in } \\
\text { first quartile }\end{array}$ & $\begin{array}{c}\text { Individual living } \\
\text { in a household } \\
\text { with income in } \\
\text { second quartile }\end{array}$ & $\begin{array}{c}\text { Individual living } \\
\text { in a household } \\
\text { with income in } \\
\text { third quartile }\end{array}$ & $\begin{array}{c}\text { Individual } \\
\text { living in a } \\
\text { household } \\
\text { with income in } \\
\text { first quartile }\end{array}$ \\
\hline $\begin{array}{l}\text { European Union } \\
\text { (28 countries) }\end{array}$ & 49 & 50 & 58 & 66 \\
\hline Belgium & 37 & 47 & 56 & 68 \\
\hline Bulgaria & 8 & 15 & 17 & 31 \\
\hline Czech Republic & 39 & 41 & 46 & 52 \\
\hline Denmark & 73 & 69 & 80 & 91 \\
\hline Germany & 72 & 77 & 26 & 36 \\
\hline Estonia & 22 & 22 & 54 & 68 \\
\hline Greece & 29 & 37 & 53 & 64 \\
\hline Spain & 23 & 64 & 68 & 81 \\
\hline France & 58 & 25 & 31 & 40 \\
\hline Italy & 20 & 35 & 44 & 46 \\
\hline Cyprus & 27 & & & 85 \\
\hline
\end{tabular}




\begin{tabular}{|l|c|c|c|c|}
\hline Latvia & 31 & 30 & 42 & 50 \\
\hline Lithuania & 23 & 26 & 33 & 46 \\
\hline Luxembourg & 55 & 70 & 79 & 90 \\
\hline Hungary & 19 & 27 & 34 & 47 \\
\hline Malta & 38 & 58 & 69 & 77 \\
\hline Netherlands & 63 & 64 & 70 & 80 \\
\hline Austria & 62 & 64 & 69 & 67 \\
\hline Poland & 41 & 41 & 48 & 56 \\
\hline Portugal & 21 & 27 & 33 & 52 \\
\hline Romania & 9 & 11 & 15 & 17 \\
\hline Slovenia & 40 & 35 & 40 & 66 \\
\hline Slovakia & 37 & 47 & 56 & 63 \\
\hline Finland & 63 & 61 & 66 & 83 \\
\hline Sweden & 63 & 72 & 74 & 84 \\
\hline
\end{tabular}

Online purchases orientation is more pronounced among young people, which highlights their greater openness to risk taking. In Table 3 we show the distribution by age group of the share of those who have made online purchases in total population who have used the Internet. Regardless of the national average, it is found in all countries a decrease in the indicator for the category over 45 years, while people between 25-44 years are the ones that stood out as having the greatest inclination to online purchase. Although it may appear some question mark, regarding the differences between the revenue of considered groups as not being able to justify different orientation to online purchases, according to Eurostat, population groups 4554 years and 55-64 years showed higher revenues than those of smaller intervals age. In this context, we conclude that age influences the orientation to online purchasing, younger people (25-44 years) assuming a greater risk of these purchases.

Table 3 Proportion of people who made online purchases in total Internet users, by age category (data for the year 2013)

\begin{tabular}{|l|c|c|c|c|c|c|}
\hline \multirow{2}{*}{ Country } & \multicolumn{6}{|c|}{ Age group } \\
\cline { 2 - 7 } & $\begin{array}{c}16-24 \\
\text { years } \\
\text { old }\end{array}$ & $\begin{array}{c}25-34 \\
\text { years } \\
\text { old }\end{array}$ & $\begin{array}{c}35-44 \\
\text { years } \\
\text { old }\end{array}$ & $\begin{array}{c}45-54 \\
\text { years } \\
\text { old }\end{array}$ & $\begin{array}{c}55-64 \\
\text { years } \\
\text { old }\end{array}$ & $\begin{array}{c}65-74 \\
\text { years } \\
\text { old }\end{array}$ \\
\hline $\begin{array}{l}\text { European Union (28 } \\
\text { countries) }\end{array}$ & 60 & 69 & 64 & 60 & 53 & 51 \\
\hline Belgium & 55 & 68 & 66 & 56 & 44 & 38 \\
\hline Bulgaria & 25 & 30 & 23 & 14 & 10 & 7 \\
\hline Czech Republic & 55 & 63 & 51 & 39 & 32 & 23 \\
\hline Denmark & 89 & 89 & 87 & 83 & 73 & 60 \\
\hline Germany & 78 & 92 & 87 & 79 & 70 & 62 \\
\hline Estonia & 33 & 42 & 30 & 20 & 13 & 8 \\
\hline Ireland & 51 & 66 & 62 & 55 & 44 & 36 \\
\hline Greece & 38 & 49 & 41 & 33 & 33 & 25 \\
\hline Spain & 40 & 51 & 48 & 39 & 34 & 23 \\
\hline France & 71 & 80 & 76 & 67 & 60 & 56 \\
\hline Croatia & 52 & 48 & 39 & 27 & 18 & 13 \\
\hline Italy & 30 & 37 & 36 & 31 & 27 & 20 \\
\hline Cyprus & 38 & 46 & 38 & 31 & 18 & 25 \\
\hline Latvia & 44 & 56 & 48 & 35 & 22 & 15 \\
\hline
\end{tabular}




\begin{tabular}{|l|c|c|c|c|c|c|}
\hline Lithuania & 42 & 51 & 39 & 25 & 18 & 11 \\
\hline Luxembourg & 77 & 82 & 75 & 74 & 66 & 59 \\
\hline Hungary & 41 & 46 & 42 & 35 & 24 & 17 \\
\hline Malta & 79 & 76 & 65 & 56 & 42 & 45 \\
\hline Netherlands & 80 & 86 & 79 & 76 & 59 & 47 \\
\hline Austria & 69 & 80 & 69 & 65 & 48 & 40 \\
\hline Poland & 50 & 63 & 53 & 36 & 31 & 22 \\
\hline Portugal & 39 & 52 & 41 & 29 & 20 & 26 \\
\hline Romania & 14 & 21 & 15 & 12 & 10 & 6 \\
\hline Slovenia & 65 & 61 & 49 & 38 & 27 & 20 \\
\hline Slovakia & 65 & 68 & 58 & 48 & 29 & 23 \\
\hline Finland & 76 & 90 & 85 & 71 & 52 & 35 \\
\hline Sweden & 82 & 84 & 83 & 81 & 65 & 54 \\
\hline United Kingdom & 86 & 93 & 86 & 83 & 79 & 73 \\
\hline
\end{tabular}

Being directly connected with income, seems to have also an influence on the orientation to online purchases. Compared to the differences in income categories, the differences in level of education categories, however, are higher. Thus, there is a greater inclination towards electronic purchases and to assuming greater risk in online purchases by people with higher level of education compared to those with medium or low level (Table 4).

Table 4. Proportion of people who made online purchases in the total of Internet users per category by level of education (data for the year 2013)

\begin{tabular}{|l|c|c|c|}
\hline \multicolumn{1}{|c|}{ Country } & $\begin{array}{c}\text { Individuals with no } \\
\text { or low formal } \\
\text { education }\end{array}$ & $\begin{array}{c}\text { Individuals with } \\
\text { medium formal } \\
\text { education }\end{array}$ & $\begin{array}{c}\text { Individuals with } \\
\text { high formal } \\
\text { education }\end{array}$ \\
\hline $\begin{array}{l}\text { European Union (28 } \\
\text { countries) }\end{array}$ & 43 & 61 & 75 \\
\hline Belgium & 38 & 55 & 74 \\
\hline Bulgaria & 9 & 18 & 30 \\
\hline Czech Republic & 37 & 54 & 61 \\
\hline Denmark & 79 & 78 & 91 \\
\hline Germany & 67 & 81 & 86 \\
\hline Estonia & 20 & 24 & 37 \\
\hline Ireland & 33 & 51 & 74 \\
\hline Greece & 18 & 34 & 55 \\
\hline Spain & 23 & 42 & 61 \\
\hline France & 52 & 69 & 86 \\
\hline Croatia & 32 & 36 & 49 \\
\hline Italy & 21 & 34 & 44 \\
\hline Cyprus & 23 & 29 & 50 \\
\hline Latvia & 26 & 36 & 52 \\
\hline Lithuania & 24 & 27 & 82 \\
\hline Luxembourg & 55 & 72 & 53 \\
\hline Hungary & 17 & 36 & \\
\hline
\end{tabular}




\begin{tabular}{|l|c|c|c|}
\hline Malta & 42 & 66 & 84 \\
\hline Netherlands & 56 & 73 & 85 \\
\hline Austria & 47 & 66 & 79 \\
\hline Poland & 34 & 42 & 66 \\
\hline Portugal & 22 & 45 & 60 \\
\hline Romania & 8 & 12 & 29 \\
\hline Slovenia & 37 & 45 & 64 \\
\hline Slovakia & 42 & 51 & 67 \\
\hline Finland & 61 & 68 & 79 \\
\hline Sweden & 68 & 75 & 84 \\
\hline United Kingdom & 59 & 83 & 93 \\
\hline
\end{tabular}

Source: Eurostat, 2014

\section{Conclusions}

In conclusion, in addition to aspects of the product such as: the novelty of the product, the level of notoriety of the brand, country of origin, value, etc., variables such as income level, age and consumer studies influence the intensity with which consumers perceive risk and it implicitly assumes. Of course there are other factors acting on the intensity with which consumers perceive the risk in time of purchase, but in the present study were taken into account variables that we found in official statistics. The study was based on data referring to the e-commerce market in the EU, in which the perceived risk plays an important role in the purchase decision.

\section{References}

Aaker, D.A., Keller, K.L. (1990), Consumer evaluations of brand extensions, Journal of Marketing, Vol. 54 No. 4, Jan. 1990, pp. 27-41

American Marketing Association (2014), available at http://www.marketingpower.com

Ashely, Richard A. (1995), Understanding your customer's perceived risk, University of Connecticut, available at http://www.hort.uconn.edu/agmarketing/distlrnarticles/percrisk.htm

Chu, P-Y; Chang, C-C; Chen, C-Y; Wang, T-Y (2010) Countering negative countryof-origin effects: The role of evaluation mode, European Journal of Marketing, Vol. 44 Iss: 7/8, pp.1055 - 1076

Delener, N. (2000), International counterfeit marketing: Success without risk, Review of Business; Spring 2000; 21, 1/2., pp. 16-20

Gurhan-Canli, Z.; Maheswaran, D. (2000), Cultural variations in country of origin effects, Journal of Marketing Research, 37 (Aug 2000), pp. 309-317

Eurostat (2014), available at http://epp.eurostat.ec.europa.eu/.

Matzler, K., Grabner-Kräuter, S., Bidmon, S. (2008), Risk aversion and brand loyalty: the mediating role of brand trust and brand affect, Journal of Product \& Brand Management, 17/3 (2008), 154-162

Nepomuceno M.V., Laroche, M., Richard M-O. (2014), How to reduce perceived risk when buying online: The interactions between intangibility, product knowledge, brand familiarity, privacy and security concerns, Journal of Retailing and Consumer Services, July 2014, Volume 21, Issue 4, 619-629

Shirin, K., Kambiz Heidarzadeh H. (2011),The Effect of the Country-of-Origin Image, Product Knowledge and Product Involvement on Consumer Purchase Decisions, Chinese Business Review, August 2011, Vol. 10, No. 8, 601-615 
Srivastava, K.; Sharma, N.K. (2011) Exploring the multidimensional role of involvement and perceived risk in brand extension, International Journal of Commerce and Management, Vol. 21 No. 4, 2011, pp. 410-427

Tian-Que, L. (2011) Perceived Risk in Marketing Strategy, International Journal of Operational Management, Marketing and Services, Volume 1, Number 1, December, 2011, pp. 8- 11. 